Н. М. Костриця

\title{
КУЛЬТУРОЛОГІЧНИЙ ПІДХІД ДО ФОРМУВАННЯ МОВНОЇ ОСОБИСТОСТІ МАЙБУТНІХ ФАХІВЦІВ АГРАРНОЇ ГАЛУЗІ
}

Костриця Н. М. Культурологічний підхід до формування мовної особистості майбутніх фахівців аграрної галузі.

У статті окреслено науково-методичні засади культурологічного підходу до формування мовної особистості майбутніх фахівців аграрної галузі та шляхи його реалізації в контексті вивчення курсу «Українська мова за професійним спрямуванням».

Ключові слова: культурологічний підхід, мовна особистість, мовна картина світу, концепт, лінгвокультурологічні завдання.

() Н. М. Костриця, 2013.

$-703-$ 
Кострица Н. Н. Культурологический поход к формированию языковой личности будущих специалистов-аграриев.

В статье обозначены научно-методические основы культуроло-гического подхода к формированию языковой личности будущих специалистов аграрной отрасли и пути его реализации в контексте изучения курса «Украинский язык профессионального направления».

Ключевые слова: культурологический подход, языковая личность, языковая картина мира, концепт, лингвокультурологические задачи.

Kostrytsia N. M. Culturological approach to the Linguistic personality formation of Agrarian affairs specialist- to-be.

The article is devoted to the main methodological basis of culturological approach to the linguistic personality formation of agrarian affairs specialists-to be and the methods of its realization in the context of «Ukrainian language according to the vocational guidance» training course.

Key words: culturological approach, linguistic personality, linguistic worldview, concept, culturological tasks.

Культурологічний підхід $є$ однією 3 тенденцій сучасної освітньої парадигми. Метою такої освіти стає людина культури, змістом - культура, як середовище, а культуротворчість - як спосіб розвитку людини в культурі.

Культурологічний підхід до формування мовної особистості фахівців-аграрників у контексті професійної підготовки передбачає піднесення їх духовності, виховання української ментальності, любові до рідного краю, мови, що інтегрує в собі розум, естетику нації, народні звичаї, традиції, загальнолюдські моральні якості і з’єднує сучасне народу з його минулим і майбутнім.

Пізнати мову не можливо, не вийшовши за їі межі, не звернувшись до іiі творця, носія, користувача - до людини, до конкретної мовної особистості. Саме мовна особистість задає координати, що визначають предмет, завдання, методи й ціннісні орієнтири мовознавства [10, с. 69]. Як зазначає Ю. Караулов, «мовна особистість - ось та наскрізна ідея, що пронизує всі аспекти вивчення мови й одночасно руйнує кордони між дисциплінами, які вивчають людину, бо не можна вивчати людину поза їі мовою» [4, с. 3].

Нині культурологічний підхід до формування мовної особистості майбутніх фахівців аграрної галузі стає пріоритетним, оскільки його реалізація сприяє використанню етнокультурного мовного матеріалу в системі їх професійної підготовки.

У лінгводидактиці проблема вивчення мови як культурознавчої дисципліни знайшла відображення в наукових розвідках таких учених: Н. Бабич, О. Біляєва, О. Горошкіної, Т. Донченко, С. Срмоленко, С. Карамана, Л. Мацько, В. Мельничайка, М. Пентилюк, О. Семеног, Т. Симоненко, М. Стельмаховича та ін. 
Мета статті - обгрунтувати перспективи вивчення курсу «Українська мова за професійним спрямуванням» у контексті культурологічного підходу для формування мовної особистості фахівця-аграрника.

Мова $\epsilon$ одним 3 найбільш універсальних засобів згортання i збереження інформації щодо транслювання та розвитку етнокультурних традицій, яка закарбована в символах. Як зазначає Е. Бенвеніст, «Через мову людина засвоює культуру, утверджує ії чи перетворює. I як кожна мова, так і кожна культура використовує специфічний апарат символів, завдяки якому впізнається суспільство» [1, с. 31-32]. Вбираючи множину знаків за способом відтворення, символіка може відтворюватися звуковими символами (пісні, гімни, географічні назви), колірною гамою (поєднання жовтого i блакитного, червоного й чорного), графічним зображенням (тризуб, хрест, стріла, коло тощо), матеріальними артефактами (одяг, посуд, рушники, реманент), продуктами харчування (борщ, галушки, вареники, сало), рослинний і тваринний світи (жито, просо, ячмінь, калина, верба, коза, корова, кінь).

Найважливішою ознакою символу $є$ його образність. Саме тому символ треба розглядати через образ. Будь-який символ є образом, але лише за певних умов образ можна вважати символом. Характерною ознакою української мови, як i будь-якої іншої загалом, $\epsilon$ iï символічність. Своєрідність символіки народу виходить 3 конкретного і неповторного життєвого досвіду етносу. Символи засновані на асоціаціях, які «завжди супроводжують процеси мислення і нерозривно пов'язані 3 конотацією» [2, с. 275]. Причиною виникнення символів $\epsilon$ потреба відновлювати забуте первинне значення слів. Внаслідок лексичного збагачення мови затемнювалося виражене словом первісне враження, виникала потреба відновлення власного значення слова [12].

Символи 'хліб' і 'земля' $є$ ключовими в контексті формування мовної особистості фахівців-аграрників, оскільки вони ввібрали в себе не лише зміст і глибинні асоціації сільськогосподарської діяльності, а й стали мовно-естетичними знаками української культури.

Природно, що мовна картина світу фахівців-аграрників не може активізувати всі загальномовні значення й значеннєві відтінки слова хліб, серед яких тлумачний словник фіксує, наприклад, такі: 1. Харчовий продукт, що випікається з борошна; 2. (тільки однина) Зерно, з якого виготовляють борошно. 3. (переважно множина) Зернові культури (жито, пшениця і т. ін.) на пні. 4. Засоби до існування; заробіток. 5. Харчі, їжа [13, с. 78-80]. Кожне з наведених словникових значень конкретизоване в словнику відповідними фразеологічними зворотами, що мають виразне оцінне значення. Найбільш розгалужена фразеологічна частина до значення 4. Засоби до існування; заробіток. Це закономірно випливає із природи буття людини, залежності іiі фізичного стану від можливостей підтримувати життя ๑) Н. М. Костриця, 2013. 
всіма «засобами до існування». Цей зміст, як i значення інших фразеологізмів із словом хліб, виявляє найсуттєвіше в людському існуванні: працею дається людині хліб; найщирішу приязнь, гостинність виявляє людина в ставленні до інших, коли пригощає їх хлібом-сіллю.

У мовній картині світу фахівців-аграрників земля має статус різнопланово конотованої одиниці, оскільки належить до стрижневих світоглядних кодів національної культури. У цій номінації найвиразніше виявляється мовний досвід колективного сприйняття землі як реалії навколишнього світу та основи національного ландшафту, способу господарювання, а відповідно - добробуту. Як зазначає Г. Булашев, «до землі український народ, як народ передовсім землеробський, почуває глибоку повагу, яка подекуди межує з обожненням» [14, с. 268].

За допомогою асоціацій мова вербалізує мовну картину світу. У контексті сказаного О. Залевська зазначає: «Вербальні асоціації відображають результати доступу через слово до інформаційного тезаурусу індивіда, за ними лежить багатогранний досвід (чуттєвий i раціональний, індивідуальний і соціальний), що забезпечує «вихід» на картину світу у всій різноманітності зв'язків та відношень» [3, с. 286].

Для українського світосприймання хліб - це найперша, найнеобхідніша іжа, очікуваний урожай (зерно), неодмінний атрибут українських звичаїв, пор.: На Новий рік хлібороб на свою худібку покладе святковий пояс $i$ квітку колосся та й веде до хати - хай $i$ воли покуитують святого хліба, бо й вони робили на нього (М. Стельмах). Асоціативні образи хліба доповнюють слова пиениия, жито, зерно, колосся, які невіддільні в мовомисленні людей-хліборобів.

Щодо образу землі, то він постає в таких асоціаціях: багатий, родючий грунт, як рідна земля, як жива істота, як мірило цінностей, як бажана мрія, як покарання, як засіб існування: «Земля - найбільше щастя - більше за любов, за життя. Земля найбільший скарб - більший за золото i коштовні речі. Земля - сон мільйонів поколінь, казкове привабливе єство, містична сила космосу, наснага слабих і дужих. Золото, краса, любов, молодість і вічний учитель мудрості! От що земля!» (У. Самчук).

Людина володіє словником не на рівні значень, а на рівні смислів, тобто концептів i концептуальних ознак. На думку В. Маслової, «концепти - це ніби згустки національнокультурних смислів, вивчення яких допомагає виявити особливості світосприйняття народу, представити концептуальну та національну картину світу» [6, с. 67]. Як зазначає М. Пименова, «концепт - це національний образ (ідея, символ), ускладнений ознаками індивідуального уявлення. На матеріалі мовних одиниць розглядаються способи представлення концептів у функціональному аспекті та за допомогою їх ознак» [9, с. 44].

На нашу думку, концепти 'хліб' i 'земля' як виразники української 
культури, національних цінностей та образів сільськогосподарської діяльності створюють свій образ мовної картини світу у фахівціваграрників. Тому для практичного втілення культурологічного підходу задля формування мовної особистості фахівця-аграрника важливого значення набуває концептна методика, під якою Н. Мішатіна розуміє теорію і практику навчання оптимальним засобам уведення в культуру (системи смислів) крізь призму мови сучасного учня як мовної особистості, носія індивідуальної картини світу [7, с. 11].

Реалізація культурологічного підходу до формуванння мовної особистості фахівців-аграрників здійснюється через лінгвокультурологічні завдання під час вивчення курсу «Українська мова за професійним спрямуванням». Лінгвокультурологічне завдання, за визначенням $\mathrm{H}$. Мішатіної, - це «добудова (або відновлення) фрагментів, яких не вистачає в емоційно-оцінній картині світу підлітка як культуромовної особистості» $[8$, с. 19].

Пропонуємо низку лінгвокультурологічних завдань, які спрямовані на опанування фахівцями-аграрниками новими смислами, пов'язаними із збереженням й вираженням національного досвіду сільськогосподарської діяльності як природо-соціокультурної реальності.

Завдання 1. Прокоментуйте фрагмент тексту:

Вона [Романова матір] й досі, мов молода, живе у своїх мріях, і досі свято вірить в усі чутки про землю, як і в те, що, ідучи по землі, можна дійти до неба, і хай Роман не вигадує всяких дурниць, хоч би вони і в книжках писалися, бо земля і небо це одне, як тіло і душа чоловіка, тільки земля - це будень людини, а небо - свято іï (М. Стельмах).

Мета завдання: активізувати асоціативне мислення спрямоване на виявлення глибокого змісту поданого речення.

Завдання 2. Пояснити значення метафор у професійному контексті.

Масний подільський чорнозем, на якому посади дитину - і дитина виросте (М. Стельмах).

Мета виконання завдання: активізувати асоціативне мислення спрямоване на виявлення глибокого змісту, виділеної в реченні метафори, застосовуючи професійні поняття і терміни.

Завдання 3. Проведіть асоціацію фольклорних символів небесних реалій: «Божа оселя», «життя», «краса, дівчини», «недобра сила», «Божий гнів», «провісниця щастя», «людські душі, які заглядають у світ».

Мета виконання завдання: провести порівняльний аналіз астрономічних понять у контексті народних знань і знайти наукові відповідники до фольклорних (народних) символів небесних реалій.

Завдання 4. Поясніть, який символічний зміст закладено у вислові I. Франка: «Іноді поступ людський виростає на могилах, як пшениця на зораній ниві!»? 
Мета виконання завдання: виявити ступінь розвитку метафоричного мислення, яке дозволяє особистості побачити значення, закодовані в символах, а також розкрити конденсований зміст, розуміння якого можна досягти через розшифрування внутрішньої форми метафори.

Завдання 5. Які асоиіаиії викликають у Вас метафори з фрагменту тексту?

Попід лісом бездоріжжям прямує чоловік, ледве чутно ворушачи губами, і тепер земля прислухається до перестуку краплин $і$ лічби хлібороба. Він міряє землю не поспіль, а по урочищах, тримаючи в пам'яті усі кроки довжини і ширини (М. Стельмах).

Мета виконання завдання: вплинути на емоційно-почуттєву сферу і викликати не лише образні, але й звукові асоціації; розвиток уміння переводити словесну інформацію в образну, звукову та навпаки.

Завдання 6. Відтворіть художній рослинний образ за висловами митиів слова.

Навкруг мене то жито половіє, а в житті купка льону голубо цвіте, то ячмінь колоситься (М. Вовчок).

Мета виконання завдання: вплинути на розвиток образного мислення як основи творчого мислення, розвиток уміння переводити словесну інформацію в образну та навпаки.

Наведемо приклади пошукових завдань, які студенти виконують користуючись відповідною літературою.

Завдання 7. Проаналізуйте трансформаиію змісту понять, скориставиись коротким словником жаргонної лексики української мови (Л. Ставиџька) та словником-довідником «Знаки украӥнської етнокультури (В. Жайворонок): Віз, капуста, карась, качан, кінь, клуня, копито, конюшня, косити, курятник, млин, мозоль, морквинка, перець, персик, плуг, скотина, стріха, цимбали.

Мета виконання завдання: розвивати вміння працювати 3 літературою, яка має різні принципи укладання, ознайомити зі способами трансформації змісту понять (наприклад через порівняння), сприяти застосуванню власного досвіду вжитку слів, понять, термінів, висловів.

Лінгвокультурологічні завдання дають можливість створювати ситуації пізнавальної новизни, зацікавленості, виявлення причиннонаслідкового зв'язку, досвіду i ціннісного ставлення, зіставлення наукових і життєвих пояснень тощо.

Завдання 8. Прочитайте уривок з тексту М. Шолохова «Піднята ичілина» $і$ доведіть вагомість народних знань у праці хлібороба.

Під дощем не можна орати, товаришу Давидов. Вам про це невідомо? Віл - не трактор. Як намокне хоч трохи в нього шерсть на шиї, враз ярмом натреш шию до крові, і тоді вже ним не робити.

- Що там таке?

- Та як же так, Давидов! Мрячить, а він оре. Та він же отак волам шиї потре! Я кажу: «Випрягай, поки дощ іде», - а він...: «Не твоє діло!» А чиє ж, сучий ти сину, це діло? Чиє, хрипливий чортяко! - закричав Майданников, 
уже звертаючись до Атаманчукова і замахуючись на нього занозом.

Мета виконання завдання: стимулювати професійне мислення, актуалізувати значення народних знань у професійній діяльності, проаналізувати поведінку персонажів і дати їй оцінку, виявити причиннонаслідковий зв'язок.

Важливу групу становлять лінгвокультурологічні завдання, які сприяють розвитку наукового мислення, формуванню умінь, необхідних у професійній та науковій роботі.

Завдання 9. Підготуйте історико-культурологічну довідку у формі презентаиї̈ про співия українського села, художника М. Пимоненка.

Мета виконання завдання: залучити студента до роботи не лише 3 навчальною літературою, але й культурологічного характеру, яка дозволить доповнити відібрану словесну інформацію образною; ознайомити студента $з$ найкращими зразками образотворчого мистецтва у професійному контексті; сприяти освоєнню і закріпленню інформатичних знань і вмінь; надати можливість студенту продемонструвати культурологічну компетентність.

Мовна картина світу розвивається не лише шляхом виявлення i фіксування нових явищ, але й за рахунок поглиблення знань про властивості вже відомих явищ і понять. У цьому контексті значний інтерес представляють лінгвокультурологічні завдання у формі опитувальників, які відображають основні терміни сільськогосподарської діяльності. Наприклад, завдання до теми: «Знаряддя обробітку грунту».

1. Яким плугом орали землю в минулому столітті (у сер. XIX ст.; 80-90-х роках XIX ст.) та напередодні війни 1914 р. (дерев’яний, сабан, саківський, самохід тощо)?

2. Де й ким виготовлявся плуг або де його купували?

3. Дати детальний опис плугів, з розмірами й місцевими назвами кожної частини й деталі, вказати форму лемеша (прямокутний, трикутний, рівнобедрений тощо). Підібрати малюнки плуга або фото.

4. Який був гряділь у дерев'яному плузі - вигнутий чи прямий і куди вигнутий - уверх чи вбік?

5. Що запрягали в плуг: коня чи вола (в шлею, в ярмо)? Яка була збруя?

6. Які типи плугів збереглися в наш час?

7. Чи орали різні грунти однаковими плугами?

8. Яка ширина борозни та глибина оранки? Чим це регулювалося?

9. Чи були якісь переваги того чи того плуга на місцевих грунтах порівняно з сучасними знаряддями оранки?

10. Якими знаряддями обробляють грунт зараз (культиватор і т. ін.)?

Використання лінгвокультурологічних завдань під час вивчення курсу «Українська мова за професійним спрямуванням» сприяє формуванню повноцінного культурологічного концепту «в єдності образного компонента, інформаційного змісту та інтерпретаційного поля» [11, с. 123].

Культурологічний підхід до формування мовної особистості фахівців- 
аграрників дає можливість інтерпретувати мовну семантику як результат культурного досвіду, тобто «Бачити мовну одиницю в якості не тільки репрезентанта конкретного мовного рівня, що володіє характерними граматичними ознаками, але й одиниці культурної пам'яті народу» [5, с. 36]. У контексті професійної підготовки фахівців-аграрників культурологічний підхід становить методологічну основу інтегрування гуманітарних знань у професійну та природничо-технічну підготовки і професійних знань у гуманітарні.

\section{Література}

1. Бенвенист Э. Общая лингвистика / Э. Бенвенист. - М. : Прогресс, 1974. - 448 с.

2. Живіцька I. Символ як стереотипізоване явище культури (на матеріалі українських паремій) / I. Живіцька // Наукові записки. - Серія : філологічні науки (Мовознавство). - Випуск 81 (3). - Кіровоград : РВВ КДПУ, 2009. - С. 271-275.

3. Залевская А. А. Психолингвистические исследования / А. А. Залевская // Слово. Текст : Избранные труды. - М. : Гнозис, 2005. - 543 с.

4. Караулов Ю. Н. Русский язык и языковая личность / Ю. Н. Караулов. - [изд. 2-е, стереотип.]. - М. : Едиториал УРСС, 2002. - 264 с.

5. Красных В. В. Этнопсихолингвистика и лингвокультурология / В. В. Красных. М. : Гносис, 2002. - 284 с.

6. Маслова В. А. Введение в когнитивную лингвистику : [учебное пособие] / В. А. Маслова. - М. : Флинта, 2004. - 293 с.

7. Мишатина Н. Л. Развитие речи учащихся на основе концептуального анализа слова / Н. Л. Мишатина // Русский язык в школе. - 2006. - № 6. - С. 19-22.

8. Мишатина Н. Л. Лингвокультурологические задачи на уроках развития речи / Н. Л. Мишатина // Русский язык в школе. - 2005. - № 4. - С. 11-14.

9. Пименова М. В. Введение в когнитивную лингвистику / М. В. Пименова. Вып. 4. - Кемерово : Наука, 2004. - 208 с.

10. Попова Е. А. Человек как основополагающая величина современного языкознания / Е. А. Попова // Фипологические науки. - 2004. - № 2. - С. 69-77.

11. Попова 3. Д. Когнитивная лингвистика / 3. Д. Попова, И. А. Стернин. - М. : АСТ : Восток - Запад, 2007. - 314 с.

12. Потебня А. А. Символ и миф в народной культуре / А. А. Потебня. - Собрание трудов. - М. : Лабиринт, 2000. - 480 с.

13. Словник української мови : в 11-и томах. - Том ХІ. - К., 1970-1980.

14. Український народ у своїх легендах, релігійних поглядах та віруваннях. Космогонічні українські народні погляди та вірування / Г. О. Булашев. - К. : Довіра, 1992. -414 c. 